Tropical Journal of Pharmaceutical Research August 2020; 19 (8): 1599-1604

ISSN: $1596-5996$ (print); 1596-9827 (electronic) (C) Pharmacotherapy Group, Faculty of Pharmacy, University of Benin, Benin City, 300001 Nigeria.

\title{
Quinolinone inhibits proliferation of gastric cancer cells and induces their apoptosis via down-regulation of the expression of pro-oncogene c-Myc
}

\author{
Wenguang Liư ${ }^{1}$, Jing $\mathrm{Ma}^{2}$, Xinrui Chen ${ }^{3}$, Baoli $\mathrm{Xu}^{3 *}$ \\ ${ }^{1}$ Department of Emergency Surgery, Linyi People's Hospital, ${ }^{2}$ Lanshan District Community Health Service Center, ${ }^{3}$ Department \\ of General Surgery, Linyi People's Hospital, Linyi, Shandong 276002, China
}

*For correspondence: Email: elf0909@126.com; Tel: 0086-0539-8211211

Sent for review: 22 February 2020

Revised accepted: 23 July 2020

\begin{abstract}
Purpose: To determine the anti-proliferative potential of quinolinone against gastric cancer cells, and the underlying mechanism of action.

Methods: Quinolinone-mediated proliferative changes were measured using 3-(4,5-dimethylthiazol-2yl)-2,5-diphenyl tetrazolium bromide (MTT) assay, while its effect on apoptosis was determined by flow cytometry. Transwell and wound healing assays were used for the determination of the effect of quinolinone on cell invasion and migration. The effect of quinolinone on protein expression levels were assayed with western blotting.

Results: Quinolinone caused reduction in gastric cancer cell viability, but it had no effect on normal (GES-1) cells. Treatment with $8 \mu \mathrm{M}$ quinolinone reduced the viability of SNU-5 and SGC-7901 cells to 32 and $27 \%$, respectively. Moreover, $8 \mu \mathrm{M}$ quinolinone induced 67.90 and $71.54 \%$ apoptosis in SNU-5 and SGC-7901 cells, respectively. Quinolinone significantly increased the population of cells in G1 phase, and suppressed migration potential $(p<0.05)$. Furthermore, in quinolinone-treated cells, the expression levels of $p-P I 3 K, c-M y c$ and $p-A K T$ were much lower than those in untreated cells $(p<0.05)$. Quinolinone also downregulated the expressions of MMP-2 and MMP-9, while it upregulated p21 expression in SNU-5 and SGC-7901 cells.

Conclusion: Quinolinone suppresses the growth of SNU-5 and SGC-7901 gastric cancer cells via cell cycle arrest, induction of apoptosis and downregulation of the expressions of c-Myc and metalloproteinases. Thus, quinolinone may be developed as a potential drug candidate for the treatment of gastric cancer.
\end{abstract}

Keywords: Gastric cancer, Apoptosis, Metalloproteinases, Phosphorylation

\begin{abstract}
This is an Open Access article that uses a fund-ing model which does not charge readers or their institutions for access and distributed under the terms of the Creative Commons Attribution License (http://creativecommons.org/licenses/by/4.0) and the Budapest Open Access Initiative (http://www.budapestopenaccessinitiative.org/read), which permit unrestricted use, distribution, and reproduction in any medium, provided the original work is properly credited.

Tropical Journal of Pharmaceutical Research is indexed by Science Citation Index (SciSearch), Scopus, International Pharmaceutical Abstract, Chemical Abstracts, Embase, Index Copernicus, EBSCO, African Index Medicus, JournalSeek, Journal Citation Reports/Science Edition, Directory of Open Access Journals (DOAJ), African Journal Online, Bioline International, Open-J-Gate and Pharmacy Abstracts
\end{abstract}

\section{INTRODUCTION}

Gastric cancer, a life-threatening disease worldwide, has very poor prognosis [1,2]. It has been reported that the incidence of gastric cancer is much higher in the developing nations of South America, East Asia and some European countries than in developed countries [3]. According to statistical data, approximately $70 \%$ of gastric cancer cases are diagnosed in 
developing nations of the world [3]. China accounts for $25 \%$ of deaths due to gastric cancer, and the average 5-year survival of the patients is $40 \%$ because the disease is diagnosed at advanced stage [4]. Gastric cancer ranks third in cancer-related mortalities worldwide, with the highest incidence in East Asia [5]. The techniques for diagnosis of gastric cancer at early stage need to be improved in order to overcome the high mortality associated with advanced stage of the disease [6]. Gastric cancer is a heterogeneous disease caused by multiple factors such as dietary salt intake, environmental factors, vitamin $\mathrm{C}$ intake, and infection with Helicobacter pylori [3]. The survival of gastric cancer patients is very unsatisfactory due to rapid recurrence and metastasis, despite improved surgical techniques, and advances in radiotherapy and chemotherapies $[7,8]$. Therefore, there is need for identification of novel bioactive anticancer compounds, as well as regulatory pathways for use in development of effective treatment for gastric cancer.

The phosphoinositide-3-kinase (PI3K)/AKT is an important signaling route associated with cancer cell proliferation, apoptosis and metastasis [9]. Studies have shown that PIK3R3, which is a regulating subunit of Class IA PI3Ks, is involved in human cancer tissues [10]. There is markedly enhanced phosphorylation of PI3K/AKT in cancer cells, when compared to normal control cells. Therefore, the inhibition of tumorigenesis by targeting PI3K/AKT activation constitutes an important therapeutic strategy for different types of cancers [11]. Quinoline, a nitrogen-bearing heterocyclic compound with aromatic nature, has been used for synthesis of various compounds of pharmacological importance [12]. The present study evaluated the anti-proliferative potential of quinolinone against gastric cancer cells, and the associated mechanism.

\section{EXPERIMENTAL}

\section{Cell lines and culture}

Gastric cancer cells (SNU-5 and SGC-7901) and normal cell line (GES-1) were provided by the Cell Bank of Chinese Academy of Sciences (Shanghai, China). The cell lines were cultured in Dulbecco's modified Eagle's medium (DMEM) supplemented with $10 \%$ FBS, $1 \%$ penicillin and $1 \%$ streptomycin at $37^{\circ} \mathrm{C}$ in a $5 \% \mathrm{CO}_{2}$ incubator.

\section{Cell proliferation assay}

The GES-1, SNU-5 and SGC-7901 cells were seeded separately, each at a density of $1 \times 10^{6}$ cells/per well in 96-well plates, and cultured for $24 \mathrm{~h}$. The cells were treated with graded doses of quinolinone $(0.25,0.5,1.0,2.0,4.0$ and $8.0 \mu \mathrm{M})$ for $48 \mathrm{~h}$. Then, $20 \mu \mathrm{L}$ of MTT solution $(5 \mathrm{mg} / \mathrm{mL})$ was added to each well, and incubation was carried out for $4 \mathrm{~h}$. Thereafter, the medium was discarded, followed by addition of $130 \mu \mathrm{L}$ of DMSO to dissolve the formazan crystals formed. The plates were shaken for $20 \mathrm{~min}$ at room temperature before optical density of each well content was read at $487 \mathrm{~nm}$ in a multi-well spectrophotometer.

\section{Apoptosis assay}

The SNU-5 and SGC-7901 cells were seeded separately, each at a density of $2 \times 10^{6}$ cells/well, and treated with $8.0 \mu \mathrm{M}$ quinolinone in 6-well plates for $48 \mathrm{~h}$. Untreated cells served as controls. The cells were washed in PBS twice before staining with $5 \mu \mathrm{L}$ of Annexin V-FITC and $10 \mu \mathrm{L}$ of $\mathrm{PI}$ in $430 \mu \mathrm{L}$ of binding buffer. The staining was carried out for 20 min in the dark at room temperature for analysis of apoptosis using a flow cytometer (Cytomics FC 500; Beckman Coulter Inc., Miami, FL, USA).

\section{Cell cycle analysis}

The SNU-5 and SGC-7901 cells were seeded separately, each at a density of $2 \times 10^{6}$ cells/well and treated with $8.0 \mu \mathrm{M}$ quinolinone in 6-well plates for $48 \mathrm{~h}$. The harvested cells were washed thrice with PBS prior to fixing with $70 \%$ methanol for $3 \mathrm{~h}$. Then, the cells were centrifuged for $4 \mathrm{~min}$ at $800 \times \mathrm{g}$, followed by washing in PBS and subsequent treatment with $480 \mu \mathrm{L}$ of buffer mixed with RNase $(10 \mu \mathrm{L})$ and $\mathrm{PI}(25 \mu \mathrm{L})$. Then, the cells were incubated in the dark for $13 \mathrm{~min}$ at room temperature, after which cell cycle analysis was done using a flow cytometer (Cytomics FC 500; Beckman Coulter Inc).

\section{Cell invasion assay}

The invasive potential of SNU-5 and SGC-7901 cells were determined in 24-well Transwell plates with $8-\mathrm{mm}$ pore size. The chamber was coated with $200 \mathrm{mg} / \mathrm{mL}$ Matrigel, followed by overnight drying. The SNU-5 and SGC-7901 cells were treated with $8.0 \mu \mathrm{M}$ quinolinone or kept untreated for $48 \mathrm{~h}$. Then, $2 \times 10^{5}$ cells in DMEM were placed on the upper chamber, while the medium containing $20 \%$ FBS was placed in the lower chamber. After incubation of the plates at $37^{\circ} \mathrm{C}$ for $48 \mathrm{~h}$, non-invasive cells were cleaned off with cotton swab. Then, the cells were fixed with 100 $\%$ methyl alcohol for15 min at room temperature, after which they were stained for $30 \mathrm{~min}$ with hematoxylin and eosin (H\&E). Cell invasion was 
determined using a light microscope (Olympus Corporation, Tokyo, Japan).

\section{Cell migration assay}

The SNU-5 and SGC-7901 cells were seeded and treated with $8.0 \mu \mathrm{M}$ quinolinone as described under apoptosis assay. Following monolayer formation, a $100-\mu \mathrm{L}$ plastic pipette tip was used to scratch a wound through the center of the wells. Loose cells were washed off with PBS, and cell migration was determined using an inverted microscope at a magnification of x200.

\section{Western blot analysis}

The SNU-5 and SGC-7901 cells were seeded and treated with $8.0 \mu \mathrm{M}$ quinolinone as described under apoptosis assay. Then, the cells were lysed by treatment with RIPA buffer [40 mM Tris$\mathrm{HCl}(\mathrm{pH} 7.4)$ along with $150 \mathrm{mM}$ sodium chloride and $1 \%(\mathrm{v} / \mathrm{v})$ Triton $\mathrm{X}-100$ in combination with protease inhibitors. The protein contents of the lysates were determined with BCA protein assay method. Then, 30- $\mu \mathrm{g}$ protein samples were resolved on $10 \%$ SDS-polyacrylamide gel electrophoresis and transferred to PVDF membranes which were previously blocked using $5 \%$ skimmed milk and $0.1 \%$ Tween-20 for $2 \mathrm{~h}$ at room temperature. The membranes were probed using anti-c-Myc, anti-p-AKT, anti-p-PI3K, antiP21, anti-MMP-2, anti-MMP-9 and anti-GAPDH (1 Cell Signaling Technology, Inc.). After washing in $1 \mathrm{X}$ PBST, the blots were incubated for $2 \mathrm{~h}$ with horseradish peroxidase-conjugated secondary antibody at room temperature. Visualization of the blots was made using ECL Reagent system.

\section{Statistical analysis}

Data are expressed are mean \pm standard deviation of triplicate experiments carried out individually. The data analysis was made with one-way analysis of variance, along with Tukey's post-hoc test Student's t-test. For analysis of data, SPSS version 17.0 software (SPSS, Inc, Chicago, IL, USA) was used. Differences were taken as significant at $p<0.05$.

\section{RESULTS}

\section{Cytotoxicity of quinolinone on SNU-5 and SGC-7901 cells}

Quinolinone reduced the viabilities of SNU-5 and SGC-7901 cells, but did not affect the viability of GES-1 cells (Figure 1). The viability of SNU-5 cells decreased to $32 \%$, whereas that of SGC-7901 cells was reduced to $27 \%$ on treatment with $8 \mu \mathrm{M}$ quinolinone. Treatment with
$0.25 \mu \mathrm{M}$ quinolinone for $48 \mathrm{~h}$ reduced the viability of SNU-5 cells to $94 \%$, while the viability of SGC-7901 cells was decreased to $91 \%$. Thus, there were significant decreases in cell viability as quinolinone concentration was increased from 0.25 to $8.0 \mu \mathrm{M}$.

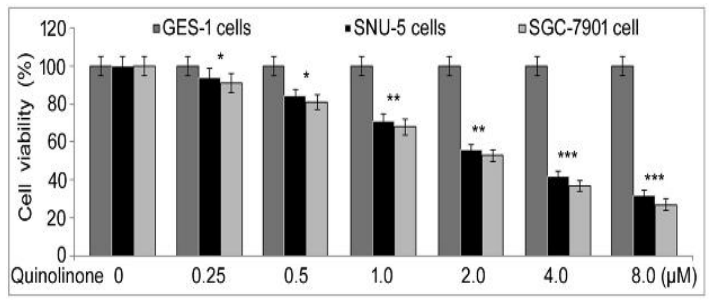

Figure 1: Effect of quinolinone on the viabilities of GES-1 (normal), SNU-5 and SGC-7901 (cancer) cells. Treatment of cells with quinolinone at doses of 0.25 $8.0 \mu \mathrm{M}$ for $48 \mathrm{~h}$ was followed by determination of cell viability using MTT assay. ${ }^{*} P<0.05$; ${ }^{* *} p<0.02$; ${ }^{* * *} p<$ 0.01 vs normal control group

\section{Quinolinone promoted apoptosis in SNU-5 and SGC-7901 cells}

Quinolinone $(8.0 \mu \mathrm{M})$ induced apoptosis in SNU5 and SGC-7901 cells after $48 \mathrm{~h}$ of treatment (Figure 2). In quinolinone-treated and untreated SNU-5 cells, apoptosis was detected in 67.90 and $1.86 \%$ cells, respectively, after $48 \mathrm{~h}$. Quinolinone $(8.0 \mu \mathrm{M})$ treatment of SGC-7901 cells resulted in $71.54 \%$ apoptosis, relative to $2.43 \%$ apoptosis in control cells. Thus, quinolinone induced apoptosis in gastric cancer cells, thereby suppressing their viability.

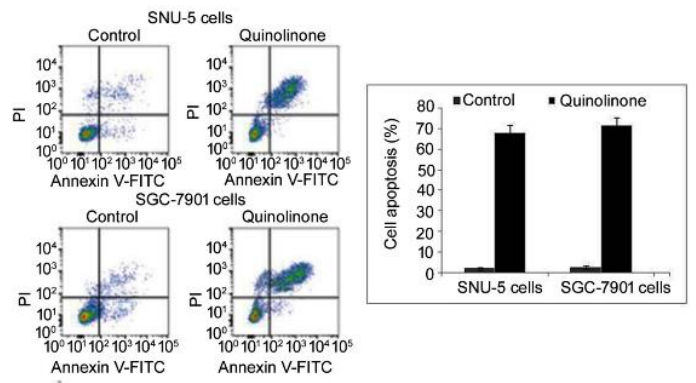

Figure 2: Apoptotic effect of quinolinone on the cell lines. Treatment of the cells with $8.0 \mu \mathrm{M}$ quinolinone for $48 \mathrm{~h}$ was followed by flow cytometric analysis of apoptosis. ${ }^{*} P<0.0456$ vs normal control group

\section{Quinolinone caused cell cycle arrest in SNU-5 and SGC-7901 cell lines}

In $8.0 \mu \mathrm{M}$ quinolinone-treated cells, the count of G1 phase cells was significantly higher than the corresponding count in untreated cells $(p<0.05)$. The count of SNU-5 and SGC-7901 cells in S and $\mathrm{G} 2 / \mathrm{M}$ phases was significantly lower in 
quinolinone-treated cell cultures than in control cells $(p<0.05)$. These results are shown in Figure 3.
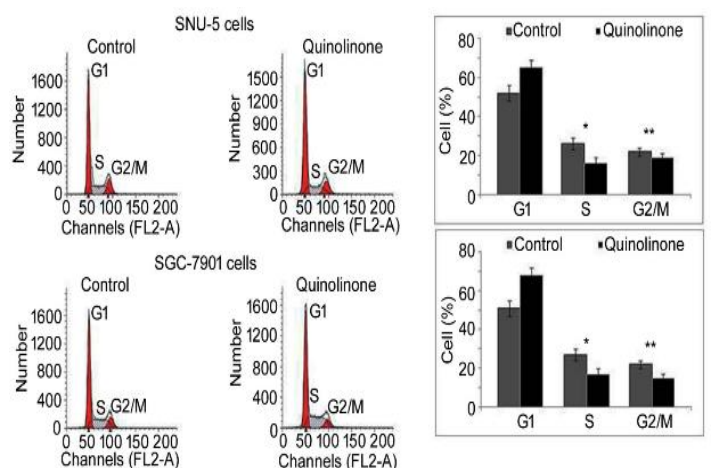

Figure 3: Effect of quinolinone on cell cycle. (A) Treatment of cells with $8.0 \mu \mathrm{M}$ quinolinone for $48 \mathrm{~h}$ was followed by flow cytometric analysis of DNA content. (B) Percentages of cells in the various phases of the cell cycle. ${ }^{\star} P<0.05$ vs normal control group

\section{Quinolinone inhibited the invasion of SNU-5 and SGC-7901 cells}

The invasiveness of SNU-5 and SGC-7901 cells was suppressed significantly by treatment with $8.0 \mu \mathrm{M}$ quinolinone for $48 \mathrm{~h}(p<0.05$, Figure 4$)$. The invasion of SNU-5 cells was decreased to $26.67 \%$, while the invasion of SGC-7901 cells was suppressed to $22.47 \%$, relative to control cells.
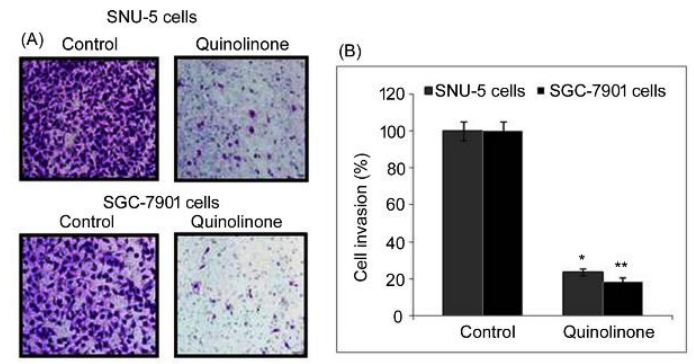

Figure 4: Effect of quinolinone on the invasiveness of SNU-5 and SGC-7901 cancer cells. (A) treatment of the cells with $8.0 \mu \mathrm{M}$ quinolinone for $48 \mathrm{~h}$ was followed by Transwell assay to determine invasion potential. (B) $\%$ invasion of cells. ${ }^{\star} P<0.046$ vs normal control group. (x200)

\section{Quinolinone inhibited the migration of SNU-5 and SGC-7901 cells}

Treatment of SNU-5 and SGC-7901 cells with $8.0 \mu \mathrm{M}$ quinolinone suppressed their migration potential to 23.43 and $18.84 \%$, respectively, relative to controls (Figure 5). Thus, quinolinone treatment regulated the invasiveness and migration potential of SNU-5 and SGC-7901 gastric cancer cells.

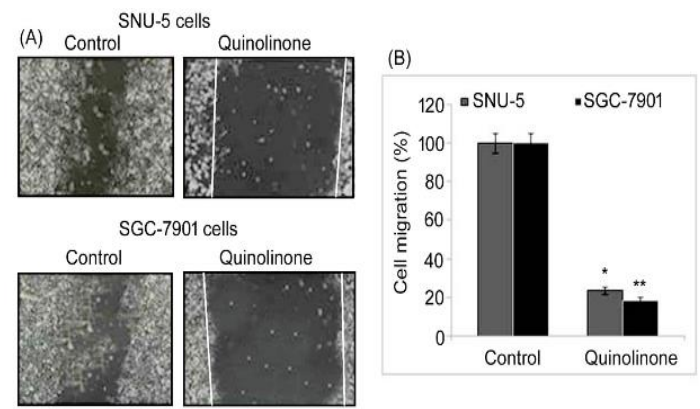

Figure 5: Inhibitory effect of quinolinone on migration potential of SNU-5 and SGC-7901 gastric cancer cells. (A) treatment of the cells with $8.0 \mu \mathrm{M}$ quinolinone for $48 \mathrm{~h}$ was followed by wound healing assays for determination of migration potential. (B) \% migration of the cells. ${ }^{*} P<0.046$ vs normal control group (x200)

\section{Quinolinone regulated PI3K/AKT signal pathway}

In quinolinone-treated cells, the expression levels of $\mathrm{p}-\mathrm{PI} \mathrm{K}, \mathrm{c}-\mathrm{Myc}$ and $\mathrm{p}-\mathrm{AKT}$ were much lower than the corresponding expressions in untreated cells. Quinolinone treatment also suppressed MMP2 and MMP9 levels in both cell lines, when compared to control. Moreover, treatment of SNU-5 and SGC-7901 cells with $8.0 \mu \mathrm{M}$ quinolinone resulted in upregulation of p21 expression, when compared to control cells. These results are presented in Figure 6.

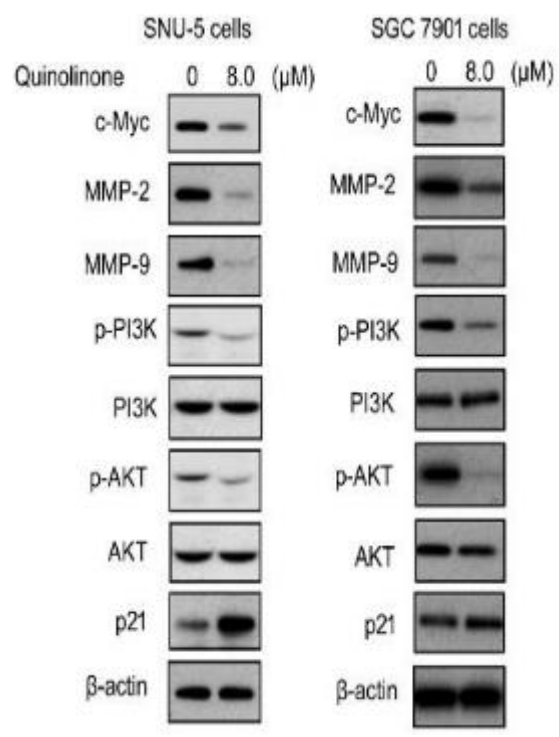

Figure 6: Effect of quinolinone on protein expressions of PI3K/AKT. Treatment of the cells with $8.0 \mu \mathrm{M}$ quinolinone for $48 \mathrm{~h}$ was followed by assay of protein expression levels using western blotting assay 


\section{DISCUSSION}

The incidence of gastric cancer has shown gradual increase over the years, and the disease continues to rank among the top malignancies worldwide [13]. Studies have reported that gastric cancer is diagnosed in more than one million people globally every year [13]. The present study has demonstrated the antiproliferative effect of quinolinone on SNU-5 and SGC-7901 cells, without any adverse effect of the viability of normal gastric cells. The enormous cell division potential of cancer cells is due to their ability to avoid apoptosis via downregulation of expressions of pro-apoptotic proteins [14]. However, oxidative stress leads to cleavage of caspases and increases in efflux of cytochrome $c$ from mitochondria through enhancement of membrane permeability [14]. These processes initiate development of apoptotic complexes, and subsequently cleave effector caspases, leading to induction of apoptosis [15].

The present study found that quinolinone exerted anti-proliferative potential against SNU-5 and SGC-7901 cells. Flow cytometry data showed that quinolinone reduced cell viabilities by increasing the proportions apoptotic cells. Moreover, treatment of SNU-5 and SGC-7901 cells with quinolinone led to blockage of the cell cycle at the G1 phase. Cell cycle arrest was evident in the marked enhancement of cell population in G1 phase and subsequent reduction in $S$ and $\mathrm{G} 2 / \mathrm{M}$ phases in quinolinonetreated cells. Furthermore, it was shown that quinolinone treatment significantly suppressed invasiveness of SNU-5 and SGC-7901 cells, relative to control cells. Moreover, cell migration abilities were markedly lower in quinolinonetreated SNU-5 and SGC-7901 cells than in untreated controls. Thus, quinolinone acted as tumor suppressor of gastric cancer. The oncogene c-Myc is associated with cellular proliferation and transformation, as well as regulation of death [16]. Studies have revealed that the inhibition of expression of c-Myc blocks the progression of cell cycle, implying that targeting the expression of c-Myc would be beneficial for enhancement of apoptosis [17-19].

The present study showed that treatment of SNU-5 and SGC-7901 cells with quinolinone resulted in downregulation of the expression of cMyc. The PI3K/AKT pathway is linked to survival and proliferation of cells, as well as angiogenesis $[20,21]$. In the quinolinone-treated SNU-5 and SGC-7901 cells, the expressions of $\mathrm{p}-\mathrm{PI} 3 \mathrm{~K}$ and $\mathrm{p}$-AKT were much lower than those in untreated cells. Thus, quinolinone arrested proliferative potential of SNU-5 and SGC-7901 cells through down-regulation of the PI3K/AKT pathway. The matrix metalloproteinases (MMP2 and MMP9) catalyze type IV collagen degradation, thereby contributing to tumor metastasis and vascularization [22]. The current study showed that quinolinone inhibited the activities of MMP2 and MMP9 in SNU-5 and SGC-7901 cells.

\section{CONCLUSION}

This study has demonstrated that quinolinone arrests growth of gastric cancer cells by blocking cell cycle and activating apoptosis. The expressions of c-Myc and metalloproteinases are suppressed in SNU-5 and SGC-7901 cells on treatment with quinolinone. Thus, quinolinone has a good potential for development into a novel drug for treatment of gastric cancer.

\section{DECLARATIONS}

\section{Conflict of interest}

No conflict of interest is associated with this work.

\section{Contribution of authors}

We declare that this work was done by the author(s) named in this article, and that all liabilities pertaining to claims relating to the content of this article will be borne by the authors. Baoli Xu - conceived and designed the study. Wenguang Liu and Jing Ma collected and analyzed the data. Xinrui Chen, Wenguang Liu and Baoli $\mathrm{Xu}$ wrote the manuscript. All authors read and approved the manuscript for publication.

\section{Open Access}

This is an Open Access article that uses a funding model which does not charge readers or their institutions for access and distributed under the terms of the Creative Commons Attribution License (http://creativecommons.org/licenses/by/ 4.0) and the Budapest Open Access Initiative (http://www.budapestopenaccessinitiative.org/rea d), which permit unrestricted use, distribution, and reproduction in any medium, provided the original work is properly credited.

\section{REFERENCES}

1. Hassanalilou T, Ghavamzadeh S, Khalili L. Curcumin and gastric cancer: A review on mechanisms of action. J Gastrointest Cancer 2019; 50(2): 185-192.

Trop J Pharm Res, August 2020; 19(8): 1603 
2. Kinoshita $H$, Hayakawa $Y$, Koike K. Metaplasia in the stomach-precursor of gastric cancer? Int J Mol Sci 2017; 18(10): pii: E2063.

3. Guggenheim DE, Shah MA. Gastric cancer epidemiology and risk factors. J Surg Oncol 2013; 107(3): 230-236.

4. Wu JG, Wang JJ, Jiang X. MiR-125b promotes cell migration and invasion by targeting PPP1CA-Rb signal pathways in gastric cancer, resulting in a poor prognosis. Gastric Cancer 2015; 18(4): 729-739.

5. Torre LA, Bray F, Siegel RL, Ferlay J, Lortet-Tieulent J, Jemal A. Global cancer statistics, 2012. CA Cancer J Clin 2015; 65: 87-108.

6. Song $Z, W u Y$, Yang J, Yang D, Fang $X$. Progress in the treatment of advanced gastric cancer. Tumour Biol 2017; 39: 1010428317714626.

7. Wang R, Deng X, Yuan C, Xin H, Liu G, Zhu Y, Jiang X, Wang $C$. IFT80 improves invasion ability in gastric cancer cell line via ift80/p75NGFR/MMP9 signaling. Int J Mol Sci 2018; 19(11): pii: E3616.

8. Yoon JH, Choi WS, Kim O, Choi BJ, Nam SW, Lee JY, Park WS. Gastrokine 1 inhibits gastric cancer cell migration and invasion by downregulating RhoA expression. Gastric Cancer 2017; 20(2): 274-858.

9. Fresno Vara JA, Casado E, de Castro J, Cejas P, BeldaIniesta C, González-Barón M. PI3K/Akt signalling pathway and cancer. Cancer Treat Rev 2004; 30(2): 193-204.

10. Bilanges $B$, Posor $Y$, Vanhaesebroeck $B$. PI3K isoforms in cell signalling and vesicle trafficking. Nat Rev Mol Cell Biol 2019; 20(9): 515-534.

11. Yang J, Nie J, Ma $X$, Wei $Y$, Peng $Y$, Wei $X$. Targeting PI3K in cancer: Mechanisms and advances in clinical trials. Mol Cancer 2019; 18(1): 26.

12. Manabuya M, Yoshihiko M, Yoshihiko S, Tetsuya K, Hideo $B$, Keizo $S$. The quinolinone derivative vesnarinone potentiates the cytotoxicity of doxorubicin in HL-60 leukemia cells. Int J Oncol 1997; 10: 53-57.

13. Guimarães RM, Muzi CD. Trend of mortality rates for gastric cancer in Brazil and regions in the period of 30 years (1980-2009). Arq Gastroenterol 2012; 49: 184188.
14. Cella D, Ivanescu C, Holmstrom S, Bui CN, Spalding J, Fizazi K. Impact of enzalutamide on quality of life in men with metastatic castration-resistant prostate cancer after chemotherapy: Additional analyses from the AFFIRM randomized clinical trial. Ann Oncol 2015; 26: 179-185.

15. Kwegyir-Afful AK, Ramalingam S, Purushottamachar $P$, Ramamurthy VP, Njar VC. Galeterone and VNPT55 induce proteasomal degradation of AR/AR-V7, induce significant apoptosis via cytochrome $c$ release and suppress growth of castration resistant prostate cancer xenografts in vivo. Oncotarget 2015; 6: 27440-27460.

16. Hermeking $H$, Eick D. Mediation of c-Myc-induced apoptosis by p53. Science 1994; 265: 2091-2093.

17. Maclean KH, Keller UB, Rodriguez-Galindo C, Nilsson $J A$, Cleveland JL. C-Myc augments gamma irradiationinduced apoptosis by suppressing Bcl-XL. Mol Cell Biol 2003; 23: 7256-7270.

18. Cannell IG, Kong YW, Johnston SJ, Chen ML, Collins HM, Dobbyn HC, Elia A, Kress TR, Dickens M, Clemens $M J$, et al. p38 MAPK/MK2-mediated induction of miR$34 \mathrm{c}$ following DNA damage prevents Myc-dependent DNA replication. Proc Natl Acad Sci USA 2010; 107: 5375-5380.

19. Shao Y, Qu Y, Dang S, Yao B, Ji M. MiR-145 inhibits oral squamous cell carcinoma (OSCC) cell growth by targeting C-Myc and Cdk6. Cancer Cell Int 2013; 13: 51.

20. De Luca A, Maiello MR, D'Alessio A, Pergameno M, Normanno $N$. The RAS/RAF/MEK/ERK and the $P I 3 K / A K T$ signalling pathways: Role in cancer pathogenesis and implications for therapeutic approaches. Expert Opin Ther Targets 2012; 16 (Suppl 2): S17-S27.

21. Aksamitiene E, Kiyatkin A, Kholodenko BN. Cross-talk between mitogenic Ras/MAPK and survival PI3K/Akt pathways: A fine balance. Biochem Soc Trans 2012; 40: 139-146.

22. Kessenbrock K, Plaks V, Werb Z. Matrix metalloproteinases: Regulators of the tumor microenvironment. Cell 2010; 141: 52-67. 